STUDIA PRAWNO-EKONOMICZNE, T. CXI, 2019

PL ISSN 0081-6841; e-ISSN 2450-8179 $\quad$ s. 243-257

https://doi.org/10.26485/SPE/2019/111/13

\title{
A SURVEY OF THE BANKS PROPERTY SCHEMES IN ITALY AND THEIR CORRELATION WITH THE BUSINESS ACTIVITY: A VIEW OF THE CATHEDRAL
}

\section{(Summary)}

The Italian banking system, largely controlled by the State during the Twentieth century, has been privatised during the Nineties. While during the State ownership a number of different types of legal bodies was active in banking, each type carrying limitations to the scope of the business, the new laws allowed only corporations to perform banking, and the adoption of the universal banking model. We will examine the various ownership schemes of a bank currently possible under the Italian law, each of whom has an impact on the actual management and, thus, on the results of the bank.

The flaws of the generally adopted universal banking model forced the community to reassess the received wisdom on the bank activity. This paper suggests one among the possible solutions: to limit the universal banking to selected subjects and allocate the various kinds of banking functions among different ownership schemes.

Keywords: Universal banking; Ownership of the firm; Great Contraction; Banking supervision JEL Classification: G21, G28, K22, K23

\section{Why the subject matter should be interesting}

The ownership of a firm is an evidently important issue when one thinks about the fact that it affects the management, the strategy and the growth of the firm, but, apparently, it does not look particularly attractive for law scholars ${ }^{1}$, especially

* Università degli Studi di Milano - Dep. of International, Legal and Political Studies; the author is primarily a practicing attorney; issues taken in the article presents the point of view of practice; e-mail: pdebiasi@gattai.it

1 Apart from the notable exception of H. Hansman, The Ownership of Enterprise, Harvard University Press, Cambridge (Mass.), 1996, there is a remarkable shortage of legal studies on the topic, apart from occasional notes of the concentrated vs. dispersed share ownership: 
in comparison with a vast economic literature, largely coming from business schools, on these topics ${ }^{2}$. To the law interpreters a different perspective is central, i.e. which is the legal body running the firm, but the point is not relevant here, because the Italian law, as we will see, made a strategic choice, requiring the banks to be incorporated as joint-stock companies or co-operatives ${ }^{3}$. Finally, the reflections on the possibility that an optimal owner of the banking business can exist and can be identified are not directly connected neither to the issue of the separation between ownership and control nor to the debate on the banking corporate governance.

The subject matter of this article is little studied, although in abstract it should draw attention for at least two reasons. Limiting the access to bank ownership is the first regulatory tool available for a regulator in order to achieve a healthy and prudent management of the bank and in fact is one of the topics of the Second Banking Directive ${ }^{4}$. Moreover, it is known from the business sciences that the structure of the property influences the management of the company, in particular in a business, such as banking, which requires not only to invest capital, but also to be ready to invest more in case capital is required to allow the continuation of the activity, in a peculiar situation, where the investor is required to disprove the old say "do not throw good money after bad money".

The article will begin with a few historical information on banking in Italy, then the ownership models of the banking enterprises will be examined, to identify the critical issues each one poses. The aim of the scrutiny is to

see J. Armour, G. Hertig, H. Kanda, Transactions with Creditors, in: R. Kraakman (ed.), The Anatomy of Corporate Law. A Comparative and Functional Approach, 3rd ed., Oxford University Press, Oxford 2017, p. 141.

2 Specifically on banks A. Zazzaro, Specificità e modelli di governo delle banche: un'analisi degli assetti proprietari dei gruppi bancari italiani, Moneta e credito 2001, p. 487, who affirms that it is not possible to define an optimal ownership structure and that the reference market can make certain schemed less suitable that other, and G. Birindelli, Strutture proprietarie e sistemi di governance, Franco Angeli, Milano, 2002. M. Tonveronachi, Regolamentazione, vigilanza e assetti proprietari nel controllo societario delle banche, Banca Impresa Società 1991, p. 69 explains the limited interest on debating over the nature of the bank ownership on the basis of the remark that the stimula to be efficient on the market for the control, come more from the market of products than form the market of the ownership.

3 Law decree no. 385 of 1 September 1993, Consolidated Banking, Art. 14.

4 Second Council Directive 89/646/EEC of 15 December 1989 on the coordination of laws, regulations and administrative provisions relating to the taking up and pursuit of the business of credit institutions and amending Directive 77/780/EEC. 
demonstrate that the generalized adoption of the universal banking model is sub-optimal and finally we will argue that the universal banking scheme must be allowed only to certain subjects and, among various solutions, our view ${ }^{5}$ is that specialized subject should perform segregated different activities.

In this article we will consider the Italian (universal) banks as a proxy for the occidental banking environment, and we will inquire whether unbundling the activities, allocating them to different types of entities could change the assessment of the optimal ownership structure.

\section{The Italian banking system from the Great Depression of the Thirties to the dawn of the nineties}

We must start spending a few lines providing the non-Italian reader with some historic information.

The crisis of the Thirties hit Italy mostly because (i) the recession rendered unbearable the implicit leverage in many banks and industrial companies, and (ii) the big banks not only had lent vast amounts of money to the industrial groups, but they also had become their shareholders. The result was that the banks suffered twice, both as lender and as shareholder, and the entire economy was nearly bankrupt.

The solution was to establish a new State agency, IRI - Istituto per la Ricostruzione Industriale (Agency for the Industrial Reconstruction), which bought the ailing big industrial conglomerates and a controlling stake in a few big banks, whose bad assets went in a bad bank.

In 1936, the new banking law provided that (i) banks were prevented to own equity in industrial companies and vice-versa, (ii) Banca d'Italia was granted independence from the Government, authorized the new to banks to start operations and supervised them, (iii) banks operated on a grid of restrictions: the bank could lend only one type of credit (mortgages, naval, fishing, agricultural, and so on) on a defined length of the facility and, apart for a dozen major banks, operating on a limited territory.

The results of the Great Depression and the reform were that the big private banks were either bankrupt or have been bought by the State, while the remaining private banks and cooperative banks were small and local. Many

The fact that this is just one view among the various possible solution justifies the reference in the title to G. Calabresi, A.D. Melamed, Property Rules, Liability Rules and Inalienability: One View of the Cathedral, Harvard Law Review, April 1972/85, p. 1089. 
banks were State institutions, in the sense that they were incorporated as "public bodies" and so credit became a "State thing", so over time people forgot it is a business, albeit of a special kind.

\section{From a fault line within banks to the one-size-fits-all principle}

The 1936 Banking Law frame-work used an empiric solution to the inherent instability of the banks' balance sheet when allowed the banks collecting medium-long term deposits to lend accordingly, while those that collected in the short term could lend in the short or in the medium-long term (real estate, mainly) only within the limits of the long term bonds they could issue and place.

In the Eighties, after the Banco Ambrosiano bankruptcy, the first Basel Capital Accord required the bank to hold a certain amount of own funds to absorb the losses. The fault line between short term and medium-long term lending faded and the Basel rules imposed the new scheme of the prudential supervision.

The State, forced to raise capital in order to comply with the rules and to allow the banks to compete in the then internationalising arena, unsuccessfully tried to issue non-voting equity ${ }^{7}$. That failure made clear that the State could not keep the control of credit institutions because it could not afford the recapitalisations and nobody accepted being junior partner. In the meantime, the Banca d'Italia in two famous papers indicated the stock company as the way out of the problem, opening the capital to private firms and individuals ${ }^{8}$.

A 1990 Act de facto forced the banks established as "public bodies" to split: the entity became sole shareholder of a company and contributed to the company the bank activity, morphing into a foundation who was intended not to keep the control of the bank. The reform, amid powerful resistances, set things in motion and a market for banks ownership was born, so the consolidation process started. Soon after the State, in a spate of State owned enterprises privatizations,

6 A. Patroni Griffi, Le crisi bancarie: il caso Ambrosiano, in: A. Patroni Griffi, Le crisi bancarie: il caso Ambrosiano, in: F. Belli, G. Minervini, F. Patroni Griffi, M. Porzio (ed.), Banche in crisi, 1960-1985, Laterza, Bari 1987, p. 136.

7 The Banca Nazionale del Lavoro issued non voting participating equity, which carried only the right to receive a dividend and went largely underwritten.

8 Banca d'Italia, Ordinamenti degli enti pubblici creditizi. Analisi e prospettive, Bollettino, 1981, n. 1-2; Banca d'Italia, Ordinamento degli enti pubblici creditizi. L'adozione del modello della società per azioni, Roma, 1988. 
privatized the big banks incorporated as stock companies, to cash the price of their sale, avoiding to pay the much needed recapitalisation'.

A new banking law, the 1993 Consolidated Banking Act "CBA"), (i) required the banks to be either joint stock companies or co-operatives and (ii) broke the fences allowing banks to become universal, or perform the same various activities though a group of joint stock companies.

\section{Universal banking and the Great Contraction}

Universal banking exists at least since the XIX century, and it went out of fashion with the Great Depression, except in Germany, where it always flourished. In the Eighties, the competition across the board required a levelled playing field, hence the Basel rules whose basic consequence was to render the universal banking an efficient solution, allowing economies of scale and cross selling. Italy accepted the universal banking model in 1994 (through the 1993 CBA), while the US repealed the much celebrated 1933 Glass Steagall Act in 1999 with the Gramm - Leach - Bliley Act.

The Great Contraction of the last decade obliged to re-think the structure of banking, but as nobody knew the answer to the famous Queen question ("Why did no one see it coming?"), nobody really knows how banks should be regulated. With the 2008 crisis came the conscience that the universal bank and, by extension, the financial conglomerates are not the rational and inevitable choice everybody thought. We can, simplifying, say that the discussion showed three main directions, namely (i) keep the universal bank model and overhaul it (ii) return to the «Glass Steagall Act», i.e. dividing the commercial banking from the investment banking and (iii) re-distribute function and services among the players ${ }^{10}$.

9 According to R. Cull, M.S. Martinez Peria, J. Verrier, Bank Ownership: Trends and Implications, March 22, 2017, IMF, WP/17/60, 2017, p. 47, in 1995, during the privatizations season, the Italian State owned $34 \%$ of the bank assets, while before the 2008 crisis it owned none.

10 On the various solutions discussed (e.g. the Liikanen Report) or actually implemented (e.g. Dodd-Franck Act) see A. Brozzetti, "Ending of too big to fail" tra soft law e ordinamento bancario europeo. Dieci anni di riforme, Cacucci, Bari, 2018. 


\section{The State as the owner}

Historically the State ownership of enterprises has been a problem ${ }^{11}$, not necessarily because its management is less efficient than the private one ${ }^{12}$, and more so when it owns a bank ${ }^{13}$. The most obvious reason is that the act of lending, mainly to the firms, becomes a political fact, hardly fitting with an economy which is not socialist (or planned) and the Italian experience in the period from the 1963 Banking Law to the Consolidated Baking Act (1993) is a testament ${ }^{14}$.

Next comes the governance. As nobody is willing to pay without having a say, the issue is the recapitalisation of banks, as the State wants to retain the control of the enterprise or, at least, a golden share, even when it is unable to recapitalise. The current EU position on State funded enterprises and more so on State bail-outs of banks is restrictive ${ }^{15}$. Furthermore the hypothesis that nowadays Western Hemisphere States can permanently allocate resources to be bankers is unrealistic, and the Greenspan put ${ }^{16}$ era is over.

11 F. Debenedetti, Scegliere i vincitori, salvare i perdenti. L'insana idea della politica industriale, Marsilio, Venezia, 2016. On the State role the discussed M. Mazzucato, The Entrepreneurial State: Debunking Public vs. Private Myths in Risk and Innovation, Anthem Press, London, 2013 stresses its importance as incubator of innovation.

12 Empirical evidence on the indifference in terms of efficiency of the firms «as long as they compete on a competitive environment» A. La Spina, G. Majone, Lo Stato regolatore, Il Mulino, Bologna 2000, p. 19.

13 R. Cull, M.S. Martinez Peria, J. Verrier, Bank Ownership: Trends and Implications..., p. 5 reports that until the Nineties scholars evidenced positive effects spilling over from the State ownership of banks, while successively the scheme was criticized, for reasons are quite similar to those indicated here.

14 See F. Merusi, Interessi e fini nei controlli sugli intermediari finanziari, Banca borsa titoli di credito 1989/I, p. 173.

15 O. Issing, Completing the Unfinished House: Towards a Genuine Economic and Monetary Union?, Center for Financial Studies, Working Paper 521, Frankfurt 2015, p. 12 said: "Economically and politically, relaxing the no-bailout clause would open the door for a massive violation of the principle of no taxation without representation, creating strong movement toward a transfer union without democratic legitimation".

16 The jargon expression summarizes the market belief the Fed, during the Greenspan tenure, would always "save" investors long on positions, pumping liquidity in the market to prevent a systemic event. The idea was not funded, but the Fed actually lowered the discount rate in two big market crises, one general (Gulf War, 1991) and one peculiar (collapse of Long Term Capital Management, 1998). 
Third problem is the selection of directors and managers, and their activity steering the bank ${ }^{17}$. In the Italian experience, directors and managers of a State owned corporation were not necessarily appraised only on their technical skills and the results they achieved, which can be measured using the balance sheet as a yardstick. Their master is not (only) driven by the profit ${ }^{18}$, it manages a very complex agenda, so the managers had been asked how they operated, for instance, in lending to the local public bodies (municipalities, local public companies providing services, ...) or to the local communities, how they served the territory or certain social groups, or whether they dismissed employees of the bank.

Finally, the State owned bank lending to a business whose direct or indirect controlling shareholder is the State, as it may still, after privatizations, happen in Italy, raises conflict of interests issues and the directors are put under political pressures.

\section{An Italian shareholder: the «banking» foundation}

While the privatization of State owned listed banks, being companies, was pretty straightforward from a legal point, the privatization of banks incorporated as "public bodies" proved much more difficult: we could transform them in stock companies sell them in the stock exchange. Actually, to avoid a glut in the market and some legal and political issues the public body become a foundation ${ }^{19}$ and spun off the banking activity, contributing it in a stock company whose shares were to be sold over time ${ }^{20}$. In reality the reform clashed with powerful resistances so that the saga of the various enacted laws lasted for more than ten years ${ }^{21}$. The reform started a reorganisation,

17 G. Rossi, Concorrenza, mercati finanziari e diritto societario, Rivista delle società 1999, p. 1305 indicates that in the State owned companies, there is «a CEO unaccountable towards non-existing boards an a more non-existing shareholder (the State)», and that the «CEO always refers politically to whom appointed him, and towards them is accountable, but not in terms of correct management or attaining the corporate goal».

18 In the same sense A. Zazzaro, Assetti proprietari delle banche e attività economica: possiamo affidarci a Coase?, Analisi Giuridica dell'Economia 2004/1, pp. 11-30.

19 The foundation ideally stays in between the State and the market: G. Guarino, Le fondazioni tra Stato, società e mercato, in: Le fondazione e le fondazioni di origine bancaria, Atti dei convegni Lincei n. 219, Bardi, Roma 2005, p. 53.

20 Formally, the mentioned Amato law did not oblige anybody and only «authorized» the public body to incorporate a joint stock company and contribute the banking activity.

21 M. Clarich, A. Pisaneschi, Le fondazioni bancarie. Dalla holding creditizia all'ente nonprofit, Il Mulino, Bologna 2001. 
rationalization and recapitalization process of the Italian banking system, but it proved impossible to force all the foundations to sell their participations ${ }^{22}$ and, even during the Great Contraction, a few foundations underwrote share issuances. Apart from a dubious capacity of the foundations, as a group, to pursue the economic efficiency ${ }^{23}$, the result has been an impoverishment of the territory and, in the most blatant case, the foundation stuck to the dogma of keeping the control of the bank. The net result was that the foundation did not diversify its participations, lost both the estate and the control of the bank, impoverished the city and denied the bank the access to capitals, badly needed for its development.

One of the reasons leading to the foundations system was to loosen the grip of political power on the appointment of the boards. The actual effect was to move the political issue from a direct nomination by the parties in Rome one step above, with the appointment of the foundation boards by local entities, i.e. the local politicians. The experience is concluded, as only a few relatively small banks ${ }^{24}$ are under joint control of foundations. Looking back, we remember that in the Sixties the State nationalised the electric powerhouses ${ }^{25}$, indemnifying the companies owning them. It was a mistake: instead of indemnifying the companies, the State should have bought the shares from the shareholders. The same mistake was made here, discarding the idea ${ }^{26}$ to transform the public bodies into companies, offer the shares to their customers and float the banks in the Stock exchange.

22 F. Mazzini, Fondazioni bancarie, in: E. Gabrielli (ed.), Commentario del codice civile, Delle persone - Leggi collegate, Utet, Torino 2014, p. 475, n. (73).

23 Ten years before the crisis V. Calandra Buonaura, Struttura proprietaria e governo delle banche, Banca Impresa Società 1998, p. 200 noted that the foundations «proved to be incapable to orient the management».

24 The largest bank ranks 31st according to Annuario $R \& S$, Mediobanca, Milano 2015.

25 G. Landi, L'espropriazione delle imprese elettriche, Rivista delle società 1963, p. 839.

26 The draft law Debenedetti S2080, XII legislature, resumed the Czech model of giving to the bank customers vouchers to purchase the bank to be privatised (P. Kenney, The Burdens of Freedom: Eastern Europe Since 1989, Zed Publishers, New York 2006, p. 10). The theoretical basis probably is M. Friedman, Curing the British Disease: the Steps from Here to There, in: Friedman on Galbraith, Fraser Institute, Vancouver 1977, p. 52, whose idea was to privatise incorporating a fund or a holding in UK, to become holder of all the State owned firms and give to the then 55 million Britons the shares of the fund: "These enterprises belong to the people; so we are going to give them to the people". 


\section{Cooperatives}

A great tradition and a strong ethic value are traditionally associated to the cooperative bank ${ }^{27}$, whose two defining rules are: the shareholding is capped $(0.5 \%)$ and the voting rule is one head, one vote. Under the CBA in Italy we have the banks "popolari", created on the model of the Raiffeisen banks, and the (smaller) cooperative credit banks. The main differences are that the latter type, by law (art. 35 CBA) must lend mostly in favour of their shareholders and insist on a narrower territory than "popolari" do. The cooperative bank is meant to be the bank of a certain district, but banks use to grow and when the banks venture out from their home base, the buzzword "mutuality" loses any meaning ${ }^{28}$.

The self-referential system to appoint directors, voted by the organised employees and retirees of the bank, allowed to substantially "co-opt" entrepreneurs of the territory, typically borrowers of the local cooperative and of a big national bank. The conflict between the director's position of creditor and debtor is clear. The system produces externalities: if the shareholders/employees can get a reward as workers, as long as they vote according to the unions and the management suggestions, they have little interest for the balance sheet. Consequently, directors are not afraid of a hostile take-over, relying on a rock solid shareholders' base, and are accountable to none.

The co-operative bank should choose whether having as shareholders the employees or, alternatively, third parties. Another solution, actually used, is that the employees (and relatives) will own shares that cannot vote for the appointment of the board, on the basis of the idea that nobody can choose her own boss.

\section{The private bank}

A bank organised as a private partnership, the original scheme used for banking, sets a limit to the development that cannot be trespassed, determined by the dry powder of the shareholders and their marginal propensity to invest, or, in other terms, eventually the growing bank will be forced to merge or prepare its IPO. Since a few years is legal in Italy that "industrial" entities become significant

27 F.D. Seminara, La speciale disciplina delle banche popolari cooperative, Giappichelli, Torino 2011, two initial chapters.

28 R. De Bruyn, G. Ferri (ed.), Le Banche Popolari nel localismo dell'economia italiana, Edicred, Roma 2005. 
shareholders of a bank and the Banca d'Italia accepts a private equity fund as controlling shareholder of a bank ${ }^{29}$. A powerful management and firewalls on the conflict of interests, which could be a simple prohibition to enter into business relationships with the shareholders, with no exceptions whatsoever, will ensure the bank stability. The model contains interesting features, the first and most obvious being that conflicts between shareholders and management are minimal, as the two groups largely overlap. Furthermore, there is empirical evidence that a bank using capitals provided by the shareholders-managers and raising from relatively few qualified lenders the money benefits from the control exercised by everybody towards everybody and the high social control is the guarantee of a smooth management. The paradigm is the most famous merchant bank, Goldman Sachs, listed in May 1999, the last among the big Wall Street investment firm to launch its IPO ${ }^{30}$.

The Italian experience of banks incorporated as unlisted joint stock companies controlled by families is scarce, so it is difficult to express an empiric judgement, while there is evidence that a few non listed banks with a huge number of shareholders exist and prosper. As they are joint stock companies, they can easily raise capital and the large number of shareholders make them potential prey of a tender offer from a competitor, a powerful incentive for managers to avoid complacency.

\section{The listed bank}

The first advantage of a listed company is being ready to raise capital, which looks now the single most important issue in banking, according to central bankers $^{31}$. The listed bank is an efficient solution for the shareholders and the market: it must disclose information on both a regular basis and when price

29 The practical limit is that private equity funds often buy with leverage and, as the bank itself is a leveraged subject, a double leverage cannot be accepted. In Italy, we had at least in one case the shareholder before the IPO was a private equity fund. See now F. Annunziata, Private Equity Funds and Qualifying Holdings in Banks: a Possible Hybridisation?, Bocconi Legal Studies Research Paper Series 2018/3232705, Milan.

30 L.J. Endlich, Goldman Sachs: The Culture of Success, Knopf, New York 1999; M. King, The End of Alchemy: Money, Banking, and the Future of the Global Economy, Little Brown, London 2016, p. 109.

31 C. Goodhart, The Basel Committee on Banking Supervision: A History of the Early Years, 1974-1997, Cambridge University Press, Cambridge 2011. 
sensitive events occur; it gives evidence of any transactions with related parties ${ }^{32}$ and these rules are stricter for banks than for other types of company.

The "dark side" of the model is its double allegiance to the banking supervisor (stability of the banking activity) and to the market watchdog (transparency and respect of market rules). The drift is incurable and is particularly severe when the bank goes through turmoil. The disclosure of immediate information (under specific circumstances) can be the disclosure of incomplete and misleading information, which can damage the bank (share prices fall, the cost of supply rises) and complicate the management in a moment of financial tension ${ }^{33}$. The second structural problem is how to set the level of disclosure to the market in the relations with customers, typically the bad debtors, which can be listed companies too. Actually, big Italian banks regularly inform the Banca d'Italia and, when asked in the AGM, they refuse to answer.

\section{The utility bank}

Instead of searching the fault lines between commercial and investment banking (US 1933 Glass-Steagall Act) or between long and short-term lending (Italian 1936 Banking Law) we could divide banks by customers.

Academics posits a low to non-leveraged bank, lending on a plain vanilla basis, which is not economically viable ${ }^{34}$. My (modest) proposal is to split the basic business of taking deposits, making payments, mortgages, personal lending

32 Under Art. 2391-bis of the Civil Code boards of listed companies must adopt rules that can ensure the transparency and the correctness of the related parties' transactions, following general principles provided by the market watchdog, the Consob (Regulation n. 17221 of 12 March 2010). The leading case is Parmalat on which Trib. Parma 29 marzo 2013, Giurisprudenza commerciale 2014/II, p. 113, note by M. Del Linz, Il nuovo caso Parmalat: considerazioni a margine di un decreto "eccessivamente creativo", Trib. Parma 11 November 2013 and App. Bologna 26 May 2014, Giurisprudenza commerciale 2015/II, p. 1027, note by N. Michieli, Denuncia di gravi irregolarità di gestione e operazioni con parti correlate.

33 Theoretically, the difference between liquidity and insolvency problems is clear. In practice, it is difficult to tell ex ante, so any decision adopted when the bank is under stress can afterwards be seen as taken on wrong hypotheses. Let us note that the liquidity support given by the lender of last resort is revealed only when the transaction has been closed, not to damage the bank: M. King, The End of Alchemy..., p. 206.

34 J. Kay, Narrow Banking. The Reform of Banking Regulation, World Economics, March 2010 www.world-economics-journal.com/Narrow\%20Banking.details?AID=402; I. Kregel, Minsky and the Narrow Banking Proposal: no Solution for Financial Reform, Levy Economics Institute of Bard College - Public Policy Brief, n. 125, 2012. 
and credit cards from corporate finance, derivatives, big corporate lending. These utility banks nowadays are no longer required to be a proximity banking, as most people use the Internet and do no longer visit the bank, so more relevant as drivers of the choice become the users' interface, the costs and the customers' service.

The granularity of the customers base will spread the risk, reducing the need for capital buffers, and, like any other utility business, the efficiency (i.e. the rewards for the shareholders) improves when dimensions grow. Furthermore, the balance sheet can be easily read and the managers' activity can be immediately monitored. As customers do not have any preference on the shareholders of the telephone or energy companies, probably, severing the link with the bank round the corner and going on the Internet they will have no preference on the bank either, preferences they express today (national or local bank, for instance). These families' banks could be owned by anybody, including the State, or be listed, in this case potentially being without a "master". Finally, the bank aiming to "serve the public" should be prevented to lend to firms larger than the small o micro enterprises.

\section{Conclusions, for the time being}

Assuming the analysis is correct, we could imagine to stop the universal banking model and pursue a division of the banking world in two segments, different in nature and ideally impenetrable. A "service to the public", providing activities like current accounts, payments, mortgages, financing the SME, purchase of State bonds and listed financial instruments, could be managed both by the local small cooperative banks and by companies operating nationwide, even listed ${ }^{35}$.

The "bank for the firm" would have as customers the medium to big companies and provide them with loans, structured finance, syndicated loans, project financing, derivatives. These activities could be run by non-listed private companies or by credit funds, whose investors are high net worth individuals or institutional investors.

A by-product of the split would be that the low complexity of the utility bank would reduce the compliance costs. As this is a fixed cost, the lower step will allow decent returns even to relatively small banks. Reciprocally, all the rules on transparency in the relationships with the customers could be reduced for the bank of the firm, letting the parties bargain.

35 In Italy we should exclude the State, owner of the quasi-bank Poste Italiane S.p.A.. 
The bank willing to serve both categories of customers and offering a full catalogue of services should do it using the most transparent structure, the listed joint stock company. It will comply with all the rules and regulations, in terms of market transparency, compliance and capital requirements, but is business scope will have an indefinite reach. The proposed arrangement will not solve the universal bank conundrum, but will limit the possible negative externalities, provided the supervisors will efficiently monitor the subjects.

\section{References}

Annunziata Filippo, Private Equity Funds and Qualifying Holdings in Banks: a Possible Hybridisation?, Bocconi Legal Studies Research Paper Series, 2018/3232705, Milan.

Armour John, Hertig Gerard, Kanda Hideki, Transactions with Creditors, in: Rainer Kraakman (ed.), The Anatomy of Corporate Law. A Comparative and Functional Approach, 3rd ed., Oxford University Press, Oxford 2017, pp. 109-143.

Banca d'Italia, Ordinamenti degli enti pubblici creditizi. Analisi e prospettive, Bollettino 1981, n. $1-2$.

Banca d'Italia, Ordinamento degli enti pubblici creditizi. L'adozione del modello della società per azioni, Roma 1988.

Birindelli Giuliana, Strutture proprietarie e sistemi di governance, Franco Angeli, Milano 2002.

Brozzetti Antonella, "Ending of too big to fail" tra soft law e ordinamento bancario europeo. Dieci anni di riforme, Cacucci, Bari 2018.

Calabresi Guido, Melamed A. Douglas, Property Rules, Liability Rules and Inalienability: One View of the Cathedral, Harvard Law Review, April 1972/85, pp. 1089-1128.

Calandra Buonaura V., Struttura proprietaria e governo delle banche, Banca Impresa Società, 1998, pp. 199-203.

Clarich Marcello, Pisaneschi Andrea, Le fondazioni bancarie. Dalla holding creditizia all'ente non-profit, Il Mulino, Bologna 2001.

Cull Robert, Martinez Peria Maria Soledad, Verrier Jeanne, Bank Ownership: Trends and Implications, March 22, 2017, IMF, WP/17/60, 2017.

De Bruyn Riccardo, Ferri Giovanni (ed.), Le Banche Popolari nel localismo dell'economia italiana, Edicred, Roma 2005.

Debenedetti Franco, Scegliere $i$ vincitori, salvare i perdenti. L'insana idea della politica industriale, Marsilio, Venezia 2016.

Del Linz Manuel, Il nuovo caso Parmalat: considerazioni a margine di un decreto "eccessivamente creativo", Giurisprudenza commerciale 2014/II, pp. 113-128.

Endlich Lisa J., Goldman Sachs: The Culture of Success, Knopf, New York 1999.

European Central Bank, Guide to fit and proper assessments, Basle, May 2017

Friedman Milton, Curing the British Disease: the Steps from Here to There, in: Friedman on Galbraith, Fraser Institute, Vancouver 1977.

Goodhart Charles, The Basel Committee on Banking Supervision: A History of the Early Years, 1974-1997, Cambridge University Press, Cambridge 2011. 
Guarino Giuseppe, Le fondazioni tra Stato, società e mercato, in: Le fondazione e le fondazioni di origine bancaria, Atti dei convegni Lincei n. 219, Bardi, Roma 2005.

Hansman Henry, The Ownership of Enterprise, Harvard University Press, Cambridge (Mass.), 1996.

Issing Otmar, Completing the Unfinished House: Towards a Genuine Economic and Monetary Union?, Center for Financial Studies, Working Paper 521, Frankfurt 2015.

Kay John, Narrow Banking. The Reform of Banking Regulation, World Economics, March 2010, www.world-economics-journal.com/Narrow\%20Banking.details?AID=402

Kenney Padraic, The Burdens of Freedom: Eastern Europe Since 1989, Zed Publishers, New York 2006.

King Mervin, The End of Alchemy: Money, Banking, and the Future of the Global Economy, Little Brown, London 2016.

Kregel Ian, Minsky and the Narrow Banking Proposal: no Solution for Financial Reform, Levy Economics Institute of Bard College - Public Policy Brief, n. 125, 2012.

La Spina Antonio, Majone Giandomenico, Lo Stato regolatore, Il Mulino, Bologna 2000.

Landi Guido, L'espropriazione delle imprese elettriche, Rivista delle società 1963, pp. 839-851.

Mazzini Francesco, Fondazioni bancarie, in: Enrico Gabrielli (ed.), Commentario del codice civile, Delle persone - Leggi collegate, Utet, Torino 2014, pp. 445-550.

Mazzucato Mariana, The Entrepreneurial State: Debunking Public vs. Private Myths in Risk and Innovation, Anthem Press, London 2013.

Merusi Fabio, Interessi e fini nei controlli sugli intermediari finanziari, Banca borsa titoli di credito 1989/I, pp. 169-182.

Michieli Nicoletta, Denuncia di gravi irregolarità di gestione e operazioni con parti correlate, Giurisprudenza commerciale 2015/II, pp. 1027-1055.

Patroni Griffi A., Le crisi bancarie: il caso Ambrosiano, in: A. Patroni Griffi, Le crisi bancarie: il caso Ambrosiano, in: Franco Belli - Gustavo Minervini - Antonio Patroni Griffi - Mario Porzio (ed.), Banche in crisi, 1960-1985, Laterza, Bari 1987.

Rossi Guido, Concorrenza, mercati finanziari e diritto societario, Rivista delle società 1999, pp. $1305-1322$.

Seminara Francesco Donato, La speciale disciplina delle banche popolari cooperative, Giappichelli, Torino 2011.

Tonveronachi Mario, Regolamentazione, vigilanza e assetti proprietari nel controllo societario delle banche, Banca Impresa Società 1991, p. 69.

Zazzaro Alberto, Assetti proprietari delle banche e attività economica: possiamo affidarci a Coase?, Analisi Giuridica dell'Economia 2004/1, pp. 11-30.

Zazzaro Alberto, Specificità e modelli di governo delle banche: un'analisi degli assetti proprietari dei gruppi bancari italiani, Moneta e credito 2001, pp. 487-517. 
Pierluigi De BIASI

\section{BADANIE SYSTEMÓW WŁASNOŚCIOWYCH BANKÓW WE WŁOSZECH I ICH KORELACJA Z DZIAŁALNOŚCIĄ GOSPODARCZĄ: ROZWAŻANIA EX CATHEDRA}

(Streszczenie)

Włoski system bankowy, w dużej mierze kontrolowany przez państwo w XX w., został sprywatyzowany w latach dziewięćdziesiątych. Podczas gdy w okresie własności państwowej w bankowości działało wiele różnych rodzajów podmiotów prawnych, z których każdy miał ograniczenia w zakresie działalności, nowe przepisy zezwalają jedynie spółkom kapitałowym na wykonywanie działalności bankowej i przyjęcie uniwersalnego modelu bankowego. W artykule autorzy analizują różne schematy własnościowe banku dopuszczalne obecnie na mocy prawa włoskiego, z których każdy ma wpływ na faktyczne zarządzanie, a tym samym na wyniki banku.

Wady powszechnie przyjętego uniwersalnego modelu bankowości wymogły ponowną ocenę form organizacyjno-prawnych działalności bankowej. W niniejszym artykule zasugerowano jedno z możliwych rozwiązań: ograniczenie bankowości uniwersalnej do wybranych obszarów i przypisanie różnych rodzajów funkcji bankowych do różnych systemów własnościowych.

Słowa kluczowe: bankowość uniwersalna; własność przedsiębiorstwa; wielki skurcz; nadzór bankowy 